УДК 616-08-035:616-002.952, DOI 10.31210/visnyk2018.04.30

(C) 2018

\author{
Юськів І. Д., доктор ветеринарних наук, професор, \\ Шидер С. I., аспірант
}

(науковий керівник - доктор ветеринарних наук, професор І. Д. Юськів)

Львівський національний університет ветеринарної медицини і біотехнологій ім. С. З. Гжицького

\title{
ЕФЕКТИВНІСТЬ ІВЕРМЕКТИНУ ЗА ПСОРОПТОЗУ КРОЛІВ І ЙОГО ВПЛИВ НА СИСТЕМУ АНТИОКСИДАНТНОГО ЗАХИСТУ ТА ПЕРЕКИСНЕ ОКИСНЕННЯ ЛІПІДІВ
}

\section{Рецензент - доктор ветеринарних наук, професор В. О. Свстаф'єва}

\begin{abstract}
Наведено дані щзодо лікувальної ефективності місцевого та системного застосування «Профіверм 1\%» (O.L.KAR., Україна), діючою речовиною якого є івермектин, за псороптозної інвазії кролів, а також вплив його на рівень ферментів антиоксидантної системи та перекисного окислення ліпідів. Виявлено, щзо як системне, так $і$ місцеве застосування засобу має виражену лікувальну ефективність (E=100\% та $96 \%$ відповідно) відносно свербунових кліщів кролів виду Psoroptes cuniculi. Гематологічними дослідженнями крові доведено, щзо найбільш ефективною лікувальною схемою є використання засобу иляхом місцевого нанесення, що підтверджується й показниками рівня ферментів антиоксидантної системи та продуктів перекисного окислення ліпідів, порівняно $з$ системним застосуванням засобу.
\end{abstract}

Ключові слова: псороптоз, кролі, кліщі, івермектин, лікувальна ефективність.

Постановка проблеми. Псороптоз - інвазійна хвороба кролів, збудником якої $\epsilon$ кліщнашкірник виду Psoroptes cuniculi. Хвороба призводить до зниження маси кролів, смертності молодняка, погіршення якості хутра та спричиняє значні економічні збитки для господарств. Отже, доречною $є$ розробка технічно простих, дешевих та ефективних схем лікування псороптозу кролів [5].

На сучасному етапі формування добробутної системи утримання кролів та згідно 3 нормативами Європейської конвенції захисту тварин важливо довести до мінімуму больові та дистресові фактори [12]. Більшість лабораторнодіагностичних та лікувальних заходів викликають у тварин біль та дискомфорт, тому сучасний досвід лікарів ветеринарної медицини намагається звести його до мінімуму. Так, забороняється знімати кірочки 3 вушної раковини кролів за псороптозної інвазії, оскільки такі дії призводять до болю у хворої тварини та виникає висока ймовірність інфікування уражених місць патогенною мікрофлорою [20]. Слід уникати використання гострих лез при приготуванні зішкрібків шкіри. 3 цією метою краще застосовувати сучасні медичні мікрошпателі 3 заокругленим кінцем - вони не травмують шкіру, є безпечними для тварини [10].

Аналіз останніх досліджень і публікацій, у яких започатковано розв'язання проблеми. Ефективність лікування акарозів кролів насамперед залежить від правильного вибору акарицидів, методів застосування їx, загального стану тварин і пори року. Добре зарекомендували себе препарати групи макроциклічних лактонів, що $€$ продуктами життєдіяльності актиноміцетів Streptomyces avermitis - івермектин, дорамектин, моксидектин, селамектин, еприномектин тощо [7-21]. Макроліди - ефективні акарициди, інсектициди та нематоциди. Наслідком дії цих препаратів є параліч і смерть членистоногих $[13,17-$ 19]. Івермектин слабко проникає у центральну нервову систему ссавців, де ГАМК також функціонує у якості нейромедіатора та стали найбільш перспективними препаратами для боротьби з членистоногими.

До сьогоднішнього часу науковці не прийшли до єдиної думки щодо дози, кратності та способу введення івермектину для елімінації Ps. cuniculi у кролів. За даними V. S. Pandey [15] встановлено, що введення івермектину в дозі $200 \mathrm{mcg} /$ кг одноразово призводить до лікувального ефекту. Поряд із тим, дослідник S. K. Curtis [8] зазначає на високу ефективність препарату у дозі $400 \mathrm{mcg} /$ кг двічі з інтервалом 18 діб. Згідно 3 даними N. P. Kurade [13], ін'єкція івермектину в дозі $200 \mathrm{mcg} /$ кг чотириразово з інтервалом 7 діб призводить до $100 \%$ ефекту. В той же час D. D. Bowman [7] зареєстрував, що дворазове застосування засобу з інтервалом 14 діб в дозі $200 \mathrm{mcg} /$ кг має високу лікувальну ефективність (99,61 \%). Повідомлення P. N. Panigrahi [16] свідчить про високу ефективність івермектину в дозі $400 \mathrm{mcg} /$ кг чотириразовово з інтервалом у 7 діб. У своїх дослідженнях Mengmeng [14] вказує на високу ефективність одноразового застосу- 


\section{ВЕТЕРИНАРНА МЕДИЦИНА}

вання твердої дисперсійної суспензії івермектину пролонгованої дії у дозі 2 мг/кг.

Слід зазначити, що поряд із високими показниками лікувальної ефективності ін'єкційних форм івермектину деякі дослідники вказують на один із важливих недоліків ін'єкційних форм препаратів, а саме больову реакцію при введенні $[11,19]$.

Враховуючи вищенаведені дані, можна зробити висновок, що пошук безболісних методів лікування кролів за псороптозу є актуальним для науки і практики завданням, що потребує вирішення.

У зв'язку з цим метою роботи було встановити ефективність препарату «Профіверм $1 \%$ жа псороптозу кролів при місцевому та системному застосуванні.

У завдання досліджень входило встановити вплив препарату на рівень ферментів антиоксидантної системи та перекисного окислення ліпідів.

Матеріали і методи досліджень. Дослідження проводили на базі віварію та кафедри паразитології та іхтіопатології ЛНУВМ та БТ імені С.3. Гжицького впродовж 2014-2015 рр. Для досліду використовували кролів каліфорнійської породи віком 6-9 місячного віку, спонтанно інвазованих кліщами виду Psoroptes cuniculi за високої інтенсивності інвазії (понад 10 кліщів у скрібку).

3 метою проведення in vitro дослідів 3 визначення ефективності препарату групи макролідів «Профіверм 1 \%», O.L.KAR., Україна з вух спонтанно хворих кроликів були відібрані кірочки із кліщами-нашкірниками Psoroptes cuniculi, яких поміщали на тканину та залишали при кімнатній температурі на 12 годин. За цей час живі кліщі 3 кірочок перемістилися на тканину. Тоді за допомогою голки кліщів розміщали у чашки Петрі по 10 шт. у кожну на фільтрувальний папір, змочений у препараті «Профіверм $1 \%$ певної концентрації. Чашки Петрі залишали на 48 годин при кімнатній температурі та вологості $80 \%$. Через 48 годин фільтрувальний папір з кліщами помі- щали під мікроскоп та досліджували їх рухливість при подразненні голкою. Відсутність ознак рухливості вважали ознакою смерті кліщів. Робочий розчин івермектину готували шляхом додавання фізіологічного розчину $\mathrm{NaCl} 0,9 \%$ до препарату до необхідної концентрації. Всього було 5 чашок Петрі (4 дослідних та 1 контрольна).

Для досліду з вивчення лікувальної ефективності засобу «Профіверм 1\%» було сформовано дві дослідних та одну контрольну групу тварин по 8 голів у кожній. Тварин першої дослідної групи обробляли вказаним препаратом у дозі 200 $\mathrm{mcg} /$ кг (0,02 мл на кг маси тіла) шляхом підшкірного введення дворазово $з$ інтервалом 7 діб. Тваринам другої дослідної групи використовували препарат у дозі $400 \mathrm{mcg} / к г ~(0,04$ мл на кг маси тіла) місцево закапуючи препарат в кожне вухо дворазово 3 інтервалом 7 діб. У контрольній групі представлені клінічно здорові тварини, яким препарат не застосовували. Ефективність препаратів визначали за формулою Абботта [6].

Гематологічні дослідження кролів дослідних і контрольних груп проводили: до початку лікування, на 7-му, 14-ту та 30-ту добу після початку лікування тварин. У цільній крові визначали: вміст каталази [2], супероксиддисмутази (СОД) [4], а у плазмі - ТБК-активних продуктів (малонового діальдегіду) [1], дієнові кон'югати [3]. Одержані цифрові дані опрацьовували статистично.

Результати досліджень. Експериментальними дослідженнями в умовах in vitro встановлено оптимальні лікувальні дози препарату, що згубно діють на кліщів виду Psoroptes cuniculi. Отримані результати наведено в таблиці 1.

Так, за наслідками досліджень встановлено, що доза івермектину $50 \mathrm{mcg}$ виявилася недостатньо ефективною щодо кліщів-нашкірників виду P. cuniculi, оскільки летальність останніх протягом 48 годин становила $50 \%$. Одночасно, $100 \%$ загибель кліщів встановлено за використання дози засобу в межах від $200 \mathrm{mcg}$ до $600 \mathrm{mcg}$.

\section{1. Тестування дози засобу «Профіверм 1 \%» на кліщах виду Psoroptes cuniculi}

\begin{tabular}{|l|c|c|}
\hline \multicolumn{1}{|c|}{$\begin{array}{c}\text { Доза препарату } \\
\text { за ДР }\end{array}$} & $\begin{array}{c}\text { Кількість дорослих кліщів } \\
\text { до досліду }\end{array}$ & $\begin{array}{c}\text { Загибель кліщів впродовж } \\
48 \text { годин, \% }\end{array}$ \\
\hline Контроль & 10 & 0 \\
\hline $50 \mathrm{mcg}$ & 10 & 50 \\
\hline $200 \mathrm{mcg}$ & 10 & 100 \\
\hline $400 \mathrm{mcg}$ & 10 & 100 \\
\hline $600 \mathrm{mcg}$ & 10 & 100 \\
\hline
\end{tabular}




\section{ВЕТЕРИНАРНА МЕДИЦИНА}

Таким чином, експериментальним шляхом в умовах in vitro встановлено, що препарат «Профіверм $1 \%$ на основі івермектину є ефективним за псороптозу кролів у дозах $200 \mathrm{mcg}$ та $600 \mathrm{mcg}$.

Встановивши оптимальні дози препарату, проведено лікувальну обробку кролів, спонтанно інвазованих кліщами виду $P$. cuniculi.

Дослідженнями встановлено, що застосування лікарського засобу «Профіверм 1\%» у дозі $200 \mathrm{mcg} / к г$ підшкірно згідно запропонованої схеми на 10-ту добу призводило до $100 \%$ ефективності засобу. Поряд із тим, місцеве застосування засобу в дозі $400 \mathrm{mcg} /$ кг маси тіла тварин шляхом дворазового нанесення 3 інтервалом у 7 діб на 10-ту добу експерименту проявляло дещо меншу ефективність - $96 \%$.

Поряд із тим, незважаючи на високі показники лікувальної ефективності івермектину за парентерального введення, дослідженнями показників кровоносного русла встановлено, що найбільш оптимальною виявилася схема 3 місцевим застосуванням засобу (табл. 2).

Так, на 7-му добу досліду у першій дослідній групі тварин рівень супероксиддисмутази та каталази були нижчими в 1,22 раза $(\mathrm{p}<0,05)$ та
1,41 раза $(\mathrm{p}<0,001)$ відповідно, порівняно з показниками в контрольній групі тварин. На 14-ту добу рівні вищевказаних ферментів дещо покращились, проте були нижчими, порівняно 3 показниками у контрольній групі тварин в 1,08 раза $(\mathrm{p}<0,05)$ та в 1,29 раза $(\mathrm{p}<0,01)$ відповідно. На кінець досліду (30-та доба) рівень ферментів дещо покращився відносно показників, що були зареєстровані на 14-ту добу, проте залишалися нижчими, порівняно 3 показниками контрольної групи (супероксиддисмутази в 1,00 раза $\mathrm{p}<0,05$ та каталази 1,14 раза $\mathrm{p}<0,01)$.

У другій дослідній групі за місцевого застосування «Профіверм 1\%» (O.L.KAR., Україна), починаючи з 7-ї доби, висока терапевтична ефективність засобу підтверджувалася й показниками крові, про що свідчить швидке відновлення рівня ферментів каталази та супероксиддисмутази, які, у порівнянні з показниками у контрольній групі, були нижчими 1,16 раза $(\mathrm{p}<0,01)$ та 1,41 раза $(\mathrm{p}<0,001)$ відповідно. На 14-ту добу досліду рівні вказаних ферментів по відношенню до показників у контрольній групи тварин були нижчими: супероксиддисмутази в 1,07 раза $(\mathrm{p}<0,05)$ а каталази - в 1,27 раза $(\mathrm{p}<0,05)$.

2. Показники активності антиоксидантної системи і вміст продуктів ПОЛ у сироватці крові кролів за псороптозу кролів у процесі застосування лікарського засобу, $M \pm m, n=8$

\begin{tabular}{|c|c|c|c|c|}
\hline Групи тварин & $\begin{array}{c}\text { Супероксид } \\
\text { дисмутаза, } \\
\text { МО/мг Нb }\end{array}$ & $\begin{array}{c}\text { Каталаза, } \\
\text { мкмоль/хв х мг Нb }\end{array}$ & $\begin{array}{c}\text { Малоновий } \\
\text { діальдегід, } \\
\text { нмоль/мл }\end{array}$ & $\begin{array}{c}\text { Дієнові } \\
\text { кон'югати, } \\
\text { нмоль/мл }\end{array}$ \\
\hline \multicolumn{5}{|c|}{ до лікування } \\
\hline $\begin{array}{l}\text { Неінвазовані } \\
\text { (контроль) }\end{array}$ & $5,51 \pm 0,491$ & $2,32 \pm 0,187$ & $2,98 \pm 0,306$ & $5,71 \pm 0,735$ \\
\hline $\begin{array}{c}\text { Iнвазовані кліщами } \\
\text { Psoroptes cuniculi }\end{array}$ & $4,28 \pm 0,55$ & $1,56 \pm 0,12$ & $4,6 \pm 0,54$ & $7,03 \pm 0,39$ \\
\hline \multicolumn{5}{|c|}{ через 7 діб після лікування } \\
\hline $\begin{array}{l}\text { Неінвазовані } \\
\text { (контроль) }\end{array}$ & $5,23 \pm 0,308$ & $2,51 \pm 0,224$ & $2,62 \pm 0,436$ & $5,75 \pm 0,869$ \\
\hline I - дослідна & $4,28 \pm 0,475^{*}$ & $1,78 \pm 0,920 * * *$ & $4,38 \pm 0,763 * *$ & $6,32 \pm 0,436^{* *}$ \\
\hline II - дослідна & $4,50 \pm 0,580 * *$ & $1,78 \pm 0,089 * * *$ & $4,1 \pm 0,800 * *$ & $6,25 \pm 1,037^{*}$ \\
\hline \multicolumn{5}{|c|}{ через 14 діб після лікування } \\
\hline $\begin{array}{l}\text { Неінвазовані } \\
\text { (контроль) }\end{array}$ & $5,25 \pm 0,513$ & $2,43 \pm 0,248$ & $2,57 \pm 0,186$ & $5,43 \pm 0,327$ \\
\hline I - дослідна & $4,85 \pm 1,002 *$ & $1,89 \pm 0,150 * *$ & $3,27 \pm 0,393 * *$ & $6,03 \pm 0,668^{* *}$ \\
\hline II - дослідна & $4,92 \pm 0,331 *$ & $1,91 \pm 0,133 * * *$ & $3,13 \pm 0,350 * *$ & $5,78 \pm 0,564^{*}$ \\
\hline \multicolumn{5}{|c|}{ через 30 діб після лікування } \\
\hline $\begin{array}{l}\text { Неінвазовані } \\
\text { (контроль) }\end{array}$ & $5,5 \pm 0,762$ & $2,32 \pm 0,322$ & $2,35 \pm 0,217$ & $5,27 \pm 0,377$ \\
\hline I - дослідна & $5,47 \pm 0,529 *$ & $2,04 \pm 0,201 * *$ & $2,6 \pm 0,369 * *$ & $5,37 \pm 0,700 * *$ \\
\hline II - дослідна & $5,62 \pm 0,467 * *$ & $2,21 \pm 0,163^{*}$ & $2,53 \pm 0,615^{*}$ & $5,28 \pm 0,574^{*}$ \\
\hline
\end{tabular}

Примітка: *-p $<0,05, * *-\mathrm{p}<0,01, * * *-\mathrm{p}<0,001$. 


\section{ВЕТЕРИНАРНА МЕДИЦИНА}

На 30-ту добу досліду рівень супероксиддисмутази був вищим в 1,02 раза $(\mathrm{p}<0,01)$, а рівень каталази - в 1,05 раза $(\mathrm{p}<0,05)$ порівняно 3 показниками контрольної групи.

Слід зазначити, що на 30-ту добу після початку лікування спостерігали повне клінічне одужання кролів обох дослідних груп та нормалізацію стану системи антиоксидантного захисту.

Вивчаючи показники продуктів перекисного окислення ліпідів у кровоносному руслі досліджуваних кролів встановлено, що місцеве застосування засобу «Профіверм 1 \%» сприяє швидшому відновленню окисних процесів у організмі хворих порівняно з показниками крові кролів за системного використання препарату.

Так, через тиждень після початку лікування у кролів першої дослідної групи рівень малонового діальдегіду та дієнових кон'югатів були вищими в 1,67 раза $(\mathrm{p}<0,01)$ та 1,10 раза $(\mathrm{p}<0,01)$ відповідно, порівняно 3 показниками контрольної групи. На 14-ту добу рівні малонового діальдегіду та дієнових кон'югатів були вищими порівняно 3 показниками у контрольній групі тварин (вище в 1,27 раза $(\mathrm{p}<0,01)$ та 1,11 раза ( $<0,01)$ відповідно). На 30-ту добу досліду рівень малонового діальдегіду та дієнових кон'югатів залишилися дещо вищими порівняно 3 контрольною групою (вище в 1,11 раза $\mathrm{p}<0,01$ та 1,02 раза $\mathrm{p}<0,01$ відповідно).

Досліджуючи показники перекисного окислення ліпідів у кролів другої групи встановлено, що на 7-му добу рівень малонового діальдегіду був вищим в 1,56 раза ( $<<0,01)$ порівняно 3 контрольною групою, а показник дієнових кон'югатів - вищим в 1,09 раза $(\mathrm{p}<0,05)$. На другий тиждень лікування спостерігали позитивну динаміку з боку стану показників перекисного окислення ліпідів. Рівень малонового діальдегіду був вищим в 1,22 раза $(\mathrm{p}<0,01)$ порівняно 3 контрольною групою, а показник дієнових кон'югатів - в 1,06 раза $(\mathrm{p}<0,05)$. На 30-ту добу досліду рівень малонового діальдегіду був вищим в

\section{БІБЛІОГРАФІЯ}

1. Коробейникова Э. Н. Модификация определения продуктов перекисного окисления липидов в реакции с тиобарбитуровой кислотой / Э. Н. Коробейникова // Лабораторное дело. 1988. - № 7. - С. 8-9.

2. Королюк М. А. Метод определения активности каталазы / М. А. Королюк // Лабораторное дело. - 1991. -№ 12. С. 9-10.

3. Стальная М. Д. Метод определения содержания диеновых конъюгатов. Современные ме-
1,00 раза $(\mathrm{p}<0,05)$ порівняно 3 контрольною групою, а показник дієнових кон'югатів - в 1,06 раза $(\mathrm{p}<0,05)$.

Слід зазначити, що через місяць від початку лікування спостерігали нормалізацію показників перекисного окислення ліпідів у обох дослідних груп. Разом із тим, у кролів другої дослідної групи процес відновлення був швидшим.

Враховуючи вищезазначене можна зробити висновок, що застосування лікарського засобу місцево має ряд переваг: створення високої концентрації препарату саме у вогнищі запалення, менша адсорбція препарату, мінімальна системна токсичність, відсутність больового шоку при використанні та простота в застосуванні.

Навпроти, використання препарату шляхом ін'єкційного введення викликає біль та додатковий стрес для інвазованого кроля, для проведення підшкірних введень необхідний досвід та допомога асистента при фіксації тварини.

\section{Висновки:}

1. Встановлено що препарат «Профіверм 1\%» (O.L.KAR., Україна) на основі івермектину $\epsilon$ ефективним за псороптозу кролів у дозах від $200 \mathrm{mcg}$ до $600 \mathrm{mcg}(\mathrm{E}=100 \%)$.

2. Ефективність препарату «Профіверм 1\%» за системного та місцевого застосування при лікуванні псороптозної інвазії кролів володіє високою терапевтичною ефективністю ( $\mathrm{E}=96-100 \%)$.

3. Встановлено, що за місцевого застосування «Профіверму 1 \%» у групі кролів, інвазованих псороптесами, швидше відбувається відновлення з боку рівня ферментів антиоксидантної системи та продуктів перекисного окислення ліпідів у порівнянні з групою тварин, де використовувалось системне використання засобу.

Перспективи подальшої роботи в цьому напрямі. Перспективами подальших досліджень $€$ розробка нових методів лікування декоративних кролів за псороптозної інвазії.

тоды в биохимии / М. Д. Стальная. - Москва, 1977. -С. 63-64.

4. Чевари C. Н. Определение антиоксидантних параметров крови и их диагностическое значение в пожилом возрасте. Лабораторное дело. 1991. - № 10. - C. 9-13.

5. Юськів І. Д. Акарологічні дослідження тварин та акарициди / і. Д. Юськів. - Львів, 1998. $95 \mathrm{c}$.

6. Abbott $W$. A method of computing the effect- 


\section{ВЕТЕРИНАРНА МЕДИЦИНА}

iveness of an insecticide / W. Abbott // Journal of the American Mosquito Control Assotiation. 1987. - №3 (2). - P. 302-303.

7. Bowman D. Effect of ivermectin on the control of ear mites (Psoroptes cuniculi) in naturally infested rabbits / D. Bowman // Am J Vet Res. 1992. - № 53 (1) - P. 105-109.

8. Curtis $S$. K. Use of ivermectin for treatment of ear mite infestation in rabbits / S. K. Curtis // J Am Vet Med Assoc. - 1990. -№ 196 (7). - P. 1139-1140.

9. Chebet J. Prevalence, control and risk factors associated with rabbit mange in Kiambu and Nyeri counties, Kenya / J. Chebet, R. M. Waruiru, K. O. Ogola // Livestock Research for Rural Development. - 2018. - № 30 (6). - P. 108.

10. Gupta Amit R. Therapeutic Management of Psoroptes Cuniculi Infestations in Rabbit with Ivermectin / Amit R. Gupta // International Journal of Livestock Research. - 2014. - № 3. - P. 28-29.

11. Kar $S$. Side reactions following ivermectin therapy in high density bancroftian microfilaraemics / S. Kar // Acta Tropica. - 1993. - № 55 (1-2). P. 21-21.

12. Kohn D.F. The importance of Analgesia (Pain Control) for pet rabbits / D. F. Kar // J Am Assoc Lab Anim Sci. - 2007. - №46 (2). - P. 97 - 108.

13. Kurade N. P. Effect of ivermectin against ear mange mite (Psoroptes cuniculi) in naturally infested rabbits / N. P. Kurade // World Rabbit Science. - 1996. - № 4 (1). - P. 25-27.

14. Mengmeng Lu. A single subcutaneous administration of a sustained-release ivermectin suspension eliminates Psoroptes cuniculi infection in a rabbit farm / Lu. Mengmeng // Drug Develop-

\section{ANNOTATION}

Yuskiv I. D., Shyder Ye. I. The efficiency of the ivermectin and its effects on the status of the antioxidant system and lipid peroxidation in rabbits infested with mites psoroptes cuniculi.

Psoroptosis is an invasive disease of rabbits caused by ear mange mites Psoroptes cuniculi. The disease leads to weight loss in rabbits, mortality of young animals, deterioration of the quality of fur and causes significant economic damage to farms. Consequently, it is appropriate to develop technically simple, cheap and effective treatment of psoroptosis in rabbits. In addition, at the present stage of formation of a well-off system for the keeping rabbits and the European Convention for the Protection of Animals, there is necessity to minimize pain and distress factors.

The purpose of our research is to determine the effectiveness of Profiverm 1\% (O.L.KAR., Ukraine) ment and Industrial Pharmacy. - 2018. - № 44 (12). - P. 1-14.

15. Pandey V.S. Effect of ivermectin on the ear mange mite, Psoroptes cuniculi, of rabbits / V. S. Pandey // Br Vet J. - 1989. - № 145 (1). P. 54-56.

16. Panigrahi P. N. Concurrent infestation of Notoedres, Sarcoptic and Psoroptic acariosis in rabbit and its management / P. N. Panigrahi, B. N. Mohanty, A. R. Gupta // J Parasit Dis. - 2016. - № 40 (3). - P. 1091-1093

17. Ravindran $R$. Cellular response to Psoroptes cuniculi / R. Ravindran // J. Vet Parasitol. - 2000. № 14. - P. 175-176.

18. Singh Sh. K. Psoroptes cuniculi induced oxidative inbalance in rabbits and its alleviation by using vitamins $\mathrm{A}, \mathrm{D} 3, \mathrm{E}$ and $\mathrm{H}$ as adjunctive remedial / Sh. K. Singh, U. Dimri // Trop. Anim. Health Prod. - 2012. - № 7. - P. 43-48.

19. Sparsa A. Systemic adverse reactions with ivermectin treatment of scabies / A. Sparsa, J. M. Bonnetblanc, I. Peyrot // Ann Dermatol Venereol. - 2006. - № 133 (10). - P. 784-787.

20. Thakre B.J. Therapeutic management of Dermatosis in Rabbits / B. J. Thakre, B. Kumar, V. Parmar // The Indian Journal of Veterinary Sciences \& Biotechnology. - 2017. - № 13. P. 88-90.

21. Uhlur J. Humoral and cellular immune response of rabbits to Psoroptes cuniculi, the rabbit scab mite / J. Uhlur // Veterinary Parasitology. 1991. - № 41 (3-4). - P. 325-334.

for rabbits infested with ear mites Ps. cuniculi with local and systemic application. The research objective is to determine the effect of ivermectinbased drug on the level of antioxidant enzymes and lipid peroxide oxidation.

It has been found that the Profiverm 1\% (O.L.KAR., Ukraine) on the basis of ivermectin is effective at doses of $200 \mathrm{mcg}$ and $400 \mathrm{mcg}(\mathrm{E}=$ $100 \%$ ) for rabbits infected with Psoroptosis.

The efficacy of Profiverm 1\% (O.L.KAR., Ukraine) for systemic and topical application for rabbits infected with Psoroptosis has high therapeutic effectiveness ( $\mathrm{E}=96-100 \%)$.

It has been found that the level of enzymes of the antioxidant system (catalase and superoxide dismutase) and lipid peroxidation products (malonic dialdehyde and diene conjugates) indicate faster reversal of oxidative processes organism following 


\section{ВЕТЕРИНАРНА МЕДИЦИНА}

topical administration of ivermectin than with subcutaneous injections in rabbits infested with ear mites Ps. cuniculi.
Key words: psoroptosis, rabbits, ear mites, ivermectin, therapeutic efficacy. 